\title{
IN THE HOTEL INDUSTRY, THE VALUE OF STAFF TRAINING - A CASE STUDY
}

\author{
D. Punitharaj ${ }^{1}$, A.Balamurugan ${ }^{2}$, Dr.Ramya Thiyagarajan ${ }^{3}$ \\ Research Scholar, BIHER, Selaiyur, Chennai $73^{1}$ \\ Research Supervisor\& Professor, Dept of Tourism \& Hospitality Management, Bharath Institute of Higher Education \\ and Research - BIHER, Selaiyur, Chennai - 73, Tamilnadu, INDIA ${ }^{2}$
}

Assistant Professor, Dept of Management Studies, TMG College of Arts and Science, Manimangalam, Chennai- 301,

Tamilnadu, INDIA ${ }^{3}$

\begin{abstract}
Human resources are the most potent sources in any organisation. The questions that every leader should consider are how to attract excellent staff and to achieve the goals of organisation. Personnel coaching is a major feature of Human Resource Management (HRM). It is a way for regulation to learn more about their workers and a way to help them become more efficient at what they do. Business success is partially ensured with the support of Human Resources Management. The goal of this research project is to help every hotel employee understand the relevance of staff training. Human Resources Management, Strategic Human Resource Management, and employee training are covered in the theoretical section. In the theory section, topics such as staff training, its value, and the benefits it provides are covered. The empirical element of the study includes both quantitative and qualitative methodologies of Fairfield by Marriott Hotel, with 53 respondents. The findings of the study indicate that employees do not entirely comprehend the need of personnel coaching; as a result, the hotel might undergo jeopardy if workers does not take training effort fully.
\end{abstract}

Keywords: - Human Resource Management, Staff training, Hotel industry

\section{INTRODUCTION}

Personnel fostering was selected because a thorough understanding of People Resource in the workplace has incalculable benefits, as well as the author's own interest in the subject after completing her practical training. Furthermore, this is an excellent opportunity to have a better understanding of Human Resource Management. Although Staff Training is only a minor portion of Human Resource Management, it is fascinating to examine it closely.

\section{Background information}

In our daily lives, the world is rapidly changing. Businesses must utilize their personnel' strengths so as to keep up with the trends. Human Resource Management, as a result, must be extensively studied and implemented. It must be capable of dealing the repercussion of inconstant work environment hence HR professionals must be aware of globalisation, technological changes, workforce diversity, labour shortages, changing skill requirements, contingent workforce, decentralised work sites, and employee involvement, among other things. Because any one of the aforementioned changes in the working process has the potential to disrupt the entire business operation, it is critical for the Human Resource Department to be prepared and in command.

Employee training has long been recognised as important and valuable by Human Resource Management. "Give a man a fish, and he'll eat for a day," as the proverb goes. a brilliant ancient Chinese scholar and philosopher, offered this smart and foresighted remark. This proverb emphasizes the importance of not only paying but also training employees to develop their capabilities.

\section{Aim of the study}

This research work will present to the readers an understanding of Human Resource Management, Staff Training, and the importance of staff training in the hotel industry, while also conducting a research on employees training as they experimented it, and gathering opinions about the tutoring in tavern from employees of various post. The author will go over the entire research work study in the conclusion section, discuss the research study results, and make comments and suggestions about employee attitudes toward staff training, as well as what the Human Resource Department can do to improve the trainings and get better results based on the research study result. Motivation of the study 


\section{International Advanced Research Journal in Science, Engineering and Technology}

Vol. 8, Issue 7, July 2021

\section{DOI: 10.17148/IARJSET.2021.8710}

The Marriott Hotel Group's specific training programme, spurred me to learn more about employee training and how important it is. Hotel employee training concepts and actions should be transferable to different business divisions within the sector.

Human Resource Management

\section{Definition}

The word itself has a basic and straightforward meaning: "human resources" refers to people, while "management" implies that it pertains to businesses and organisations. Human Resource Management is a broad term that varies by industry and differs in academic research and practical application. "Human Resources Management" is defined by Gary Dessler as "the policies and practices involved in carrying out the people or human resource parts of a management role, such as hiring, screening, training, rewarding, and appraising." Interviewing analyses, choosing eligible and appropriate applicants, training, development plans and enforcement, controlling salaries, offering employee benefits and rewards, and so on are examples of these practices and policies.

In 1999, the South African Steering Committee for Human Resources Management Standards \& Qualifications defined Human Resources Management as "all the decisions, strategies, factors, principles, operations, practices, functions, activities, and methods related to the management of people as employees in any type of organisation; all the decisions, strategies, factors, principles, operations, practices, functions, activities, and methods related to the management of people as employees in any type of organisation; all the decisions, strategies, factors, principles, operations, practices, functions, activities, and methods; All of this is targeted at adding value to the supply of goods and services, as well as the quality of workers' work lives, and so ensuring organisational success in transforming environments."

\section{Roles of Human Resources Management}

A good Human Resources Management team is organised, and everyone on the team has their own responsibilities, such as job analysis, recruitment, training, and evaluation.

Job analysis

According to the website, "job analysis" is described as "the process of analysing the obligations of various vocations as well as the characteristics of people who should be employed to fulfil them." When someone mentions dessler, the word dessler comes to mind. All other departmental functions are built on the foundation of job analysis. Human Resources Management identifies which positions are required during the job analysis and generates a job description that describes the tasks, responsibilities, and activities of each role.

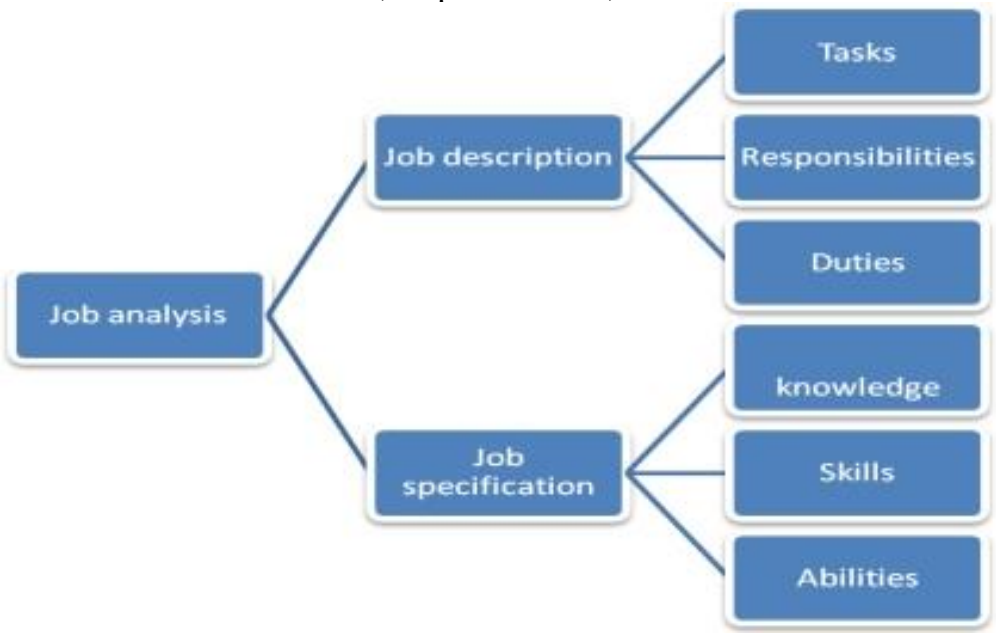

Figure 1 Job analysis

\section{Recruiting}

Human resource workers are in charge of recruiting and they should know the number of employees to hire and appropriate persons to be hired based on the job analysis (Figure 2). Internal recruitment and external recruitment are the two types of recruitment. As the name implies, HR DEPARTMENT can hire individuals within the business (Table 1), changes from a office, or other type of professional development. External recruiting refers to hiring from outside sources.

Table 1 Internal and external recruiting sources 
International Advanced Research Journal in Science, Engineering and Technology

Vol. 8, Issue 7, July 2021

DOI: $10.17148 /$ IARJSET.2021.8710

\begin{tabular}{|l|l|}
\hline Internal sources & External sources \\
\hline Job posting & Advertisements \\
\hline Newsletter & Employment agencies \\
\hline Employee as referral sources & Schools, colleges and universities \\
\hline Recommendations by current employee & Professional organizations \\
\hline- & Online recruiting \\
\hline
\end{tabular}

Training

After successfully and carefully selecting new employees, they must be trained to work on the job. Orientation will be provided at the start of their employment, and other types of training will follow.

\section{Evaluating}

Employees must undergo performance reviews throughout time; the evaluation is based on input from their departments' representatives, coworkers, and the training process, among other things. The evaluation inspires and inspires people to perform harder and better in the future, as well as assisting them in improving their skills and abilities through rewards, compensation, and more practise.

\section{Aim of Human Resource Management}

People differ in many ways; they have different skills, abilities, and knowledge that will or will not meet the needs of the organisation; some devote themselves to their work, while others see it as a steady source of income; they are underutilised, resulting in an unbalanced situation on their performance.

According to Armstrong, human resources management attempts to achieve organisational goals by hiring, training, and developing employees. Its purpose is to inspire people to be more productive and profitable by maximising their abilities and potential. Human Resources Management assists the organisation in creating conditions that encourage people to innovate, collaborate, and develop skills, as well as an environment in which they can express their creativity and energy. Individuals will associate themselves with the organization's success if they perform better with HRM's help. Human resource management is to match HR policies to corporate goals and plans.

\section{Strategic Human Resources Management}

\section{Definition}

"Strategic Human Resource Management means formulating and executing HR systems-HR policies and practice - that produce the employee competencies and behaviors the company needs to achieve its strategic aims." (Dessler 2006, 11). The aim of Human Resources Management in Strategic Human Resource Management is to achieve corporate objectives.

In terms of management concept, content, and practise, Strategic Human Resource Management and Human Resource Management are separate. As a result of human resources being brought into the boardroom and the Human Resource Department being tied to the organization's goals, strategic human resource management has advanced. The human resources of the organisation were effectively utilised, resulting in commercial success.

\section{Aim of Strategic Human Resource Management}

"The purpose of strategic human resource management is to ensure that the company's economic goals are met by the corporate culture, attitude, and framework, as well as the expertise, passion, and enhancements of employees." (Armstrong, p. 47, 1992) Strategic human resource management connects human resources to employee tactics by utilising resources to achieve organisational goals and adjusting human resources in accordance with standards, such as decreasing or shifting personnel to relevant jobs. It also tries to educate and develop individuals so that, in the face of workplace rivalry, they can maintain their assets and features. Strategic human resource management aims to assess, educate, and inspire individuals based on their abilities.

\section{Key benefits of a Strategic Human Resource Management system}

There are certain clear benefits when Human Resource Management and business plans are linked; as a result, more and more firms are tying Human Resource Management and business plans together. Strategic Human Resource Management ensures that every employee is working toward the same goal, which is to satisfy customers; and it enables employees to reach their effort as they can excel at work. Strategic Human Resource Management places a 


\section{International Advanced Research Journal in Science, Engineering and Technology}

Vol. 8, Issue 7, July 2021

\section{DOI: $10.17148 /$ IARJSET.2021.8710}

greater emphasis on the consequences and efficacy of human resource development, resulting in more sophisticated and efficient human resource management. The Strategic Human Resource Management system also aids in the development of a foundation for organisational transformation, such as hiring additional employees or laying off some employees in accordance with recurring strategies.

Staff Training

"Training is a method of providing knowledge and skills to employees so they can work within management's procedures and practices." the number 2082007 (Sommerville). "At its most fundamental level, training is an undertaking that modifies people's behaviour." Staff training, as originally said, is an important component of Human Resource Management tasks. As the workplace evolves and grows more sophisticated, more businesses recognize the need of continuing education.

\section{Staff training in hotel industry}

In today's hotel industry, people's competence, particularly staff qualities, is crucial. Employee qualities influence the quality of service provided. Knowledge, abilities, and concepts are among the factors that contribute to a hotel's survival and growth. Employee training, as a result, is critical in a number of ways: it generates wealth by equipping employees with professional expertise, experienced skills, and viable ideas; it also motivates and inspires workforce by offering all necessary information at work.

\section{The importance of staff training}

Staff training is an important aspect of Human Resource Management and Development, as well as a significant role; it is a critical method for empowering staff and enhancing performance at work. Employees are being asked to be more skilled and qualified as technology and the business environment evolve. Even if you are a competent employee now, you could be out of the line tomorrow if you do not continue to study. If a corporation wants to compete, it must invest in coordinated employee training.

The most important role in assisting everyone else in the firm to become more cohesive is to provide professional development. An organisation could hire or train skilled people. Team work should be encouraged amongst personnel and management team members when the organisation trains their own personnel by supplying and establishing a harmonious environment, precise work specifications, and a love for work. One of the most important components of staff training is task training, which includes work principles, career knowledge, and dexterity.

\section{Benefits of staff training}

Personnel coaching improves their skills and gives them a leg up on the competition. Effective training will improve both personal and business capacities. Staff training benefits patrons, guests, collaborators, administration, and the organisation as a whole.

Benefits the employee

- Increases job satisfaction and recognition

Employees will be introduced to what the job entails, how to accomplish it, and what part the position plays in the overall business during the training. This will help them better understand their work and, as a result, appreciate what they do.

- $\quad$ Encourages self-development and self-confidence

Employees will appreciate the importance of their tasks after receiving systemized training, and they will be more confidence in their work as a result of the information, knowledge, and experiences gained throughout the training.

- $\quad$ Helps the employee become an effective problem solver

- $\quad$ Employees will learn how to solve problems or complaints during training, which will be taught and guided by practical experience.

- $\quad$ Allows the employee to become productive more quickly

Employees gain familiarity with their work tasks, improved information, and practises through training, which improves their skills and productivity

\section{Benefits the management}

- $\quad$ Aids in evaluating employee performance

People who are in charge of training will identify those employees who are quick learners, who have more knowledge and skills, so that different training techniques may be used, and therefore better outcomes may be achieved.

- $\quad$ Aids in sustaining systems and standards 


\section{International Advanced Research Journal in Science, Engineering and Technology}

Vol. 8, Issue 7, July 2021

\section{DOI: 10.17148/IARJSET.2021.8710}

Employees will be introduced to the hotel's foundations and standards, along with policies and processes, throughout the training, allowing the hotel to maintain its standards and system.

- Helps identify employees for promotions or transfers

Experienced trainers will immediately identify employees' abilities and personalities during training, and if some employees are better suited to other professions, hotels may alter and make the greatest use of employees' intellectual capabilities

Benefits the organization

- $\quad$ Because of enhanced output and improved care as a result of the training, the hotel is more apt to consider additional profit.

- $\quad$ Reduces mishap and infringement

- $\quad$ Aids in organizational development

- Hotels must develop their technologies and techniques of operation in order to remain competitive, and staff training ensures this competitiveness by bringing high quality, efficiency, and loyal clients to the hotel. Reduces wastage and costly employee turnover Wastage and damages in different departments are commonly found out in hotel operation, with the help of staff training; unnecessary wastage and damages can be avoided. Regular trainings can decrease work pressures and employee turnover, as a result, less labor cost will be spent and better service can be achieved.

\section{The Training process}

\section{Assessing the training needs}

\section{Evaluating}

planning

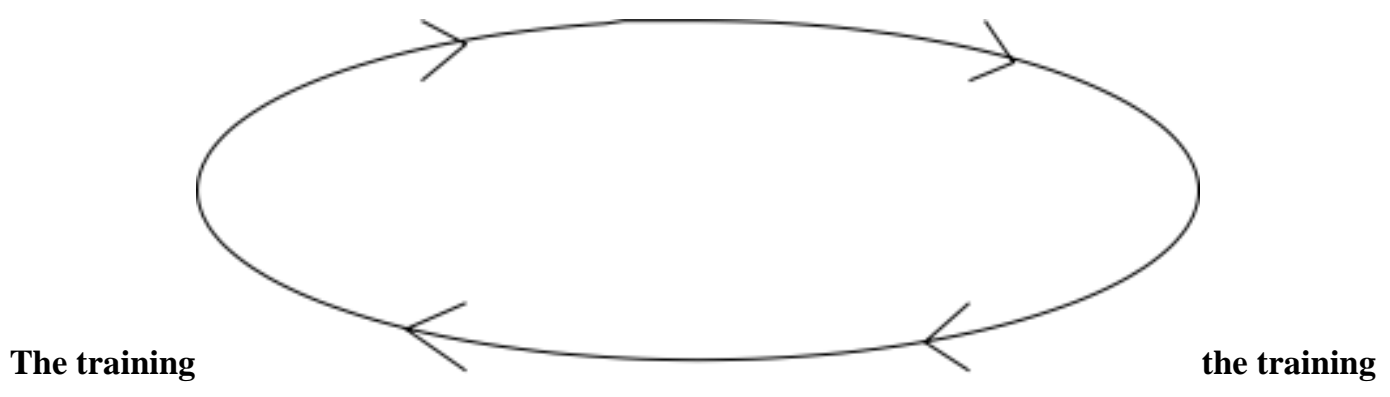

Carrying out the train
Figure 2 Training Cycle

The training cycle is circular (Figure 2), and it starts with a requirements assessment. The disparity between an ideal expectation for employee performance and actual performance always results in the requirement for training. New employees can also receive training to assist them become acquainted with the work environment, tasks, and so forth. Job analysis, performance objectives, and other related elements should be considered by the HR department.

The planning of the training is the second step in the training cycle. Specifying training objectives, creating a training programme, and selecting training methods are all part of the planning process. Practical difficulties such as training goals, training method, duration, programme structure, location and participant enrollment, and so on must be addressed at the planning stage. Following the successful preparation of the training, the training programme should be carried out according to the plan. The trainer must be well-prepared and skilled, and the trainees must be actively engaged in the training. The performance assessment is a variance equation in the training process; receiving feedback aids in the adjustment and organisation of future trainings. This is the time to make plans for future training. Evaluation is the final part of a training cycle, but it also serves as the foundation for the next one.

Types of staff training

Training objects

Top management, supervisory management, and front line personnel that participate in operations and provide 


\section{International Advanced Research Journal in Science, Engineering and Technology}

Vol. 8, Issue 7, July 2021

\section{DOI: $10.17148 /$ IARJSET.2021.8710}

services all receive different types of training. The organizational culture, which describes the general manager, directors, managers, and assistant managers from each department, is in charge of deciding judgments. It has to focus on creating sensible economic perspectives, marketing, developing sales strategies, budgeting, and cost control, among other topics. The supervisory management group is the organization's administrative team, which includes supervisors, team leaders, and so on. They should be taught about management techniques and abilities, as well as expert knowledge, customer relations, and how to sample cases and objections from guests, among other things. Front-line employees contribute to the hotel's overall operation; training for them should focus on professional knowledge, technical competences, and working attitudes in order to increase their talents.

\section{Training location}

Trainings are classified as in-house training, on-the-job training, or outside training based on where they take place. The Human Resource department organises in-house training, which takes place at facilities and amenities such as the training room and the staff cafeteria. Each department is usually responsible for on-the-job training; supervisors, team captains, and trainers are in charge of this, and the employee is trained by an experienced colleague or trainer. The term "outside training" consists of training that takes place outside of the hotel. Trainees attend events and conferences, participate in training programmes established by independent organisations, or travel internationally for training at sister resorts.

Training contents

Trainings are performed for a plethora of ways; some are conducted to assist new employees in becoming acquainted with the hotel; others are held to improve employees' core competencies; so, trainings can be categorized according to their subject:

\section{- $\quad$ Apprentice training}

To provide new employees with tremendous challenges about the hotel as well as the basic skills they will need on the job. This training aids in the development of positive connections among colleagues as well as between employees and management. Furthermore, it aids personnel in favorable attitudes toward profession.

- $\quad$ Certification training

Employees who accomplish this type of training receive a professional certificate based on practical or conceptual assessments. Its goal is to develop employees' capabilities while also motivating them to complete the course.

- $\quad$ Simulation training

With the cooperation of the Human Resource Department, industrial knowledge is held with the goal of improving employment methods and increasing job efficacy by replicating the real workplace. Because this training is used in regular work, it is long-term. Department heads play a crucial role in achieving reliable results from this training by employing effective training tactics.

- $\quad$ Language training

Tavern personnel must be capable in communicating at least one foreign language. Sector, occupational category, and prestige all have different linguistic criteria. Because English is an internationally used language, every member of staff should be able to communicate in it. Different language may be required or learnt depending on the hotel's location..

- Hotel services and administration training

This orientation is too dependent on a particular issue, such as telephone tactics, concierge, product knowledge, strategic communications specific information and implementation, hygiene and first-aid, and so on, in order to improve governance and activities.

\section{- $\quad$ Cross training}

Cross training is used to aid employees in receiving content and resources from other departments in order to ensure communication between departments and enhance their capability to adjust to different environments.

\section{Staff Training in an international perspective}

Because the hospitality industry is frequently handled on an international basis, employee training should be globalized as well. When planning and construction trainings, cross-cultural training has to be taken into account. In foreign employee training, training program has become extremely crucial. Training program in International Marketing (International Human Resource Management) is deployed in a number of ways, including attending courses and lectures at various schools or training sites, as well as using equipment such as observations, archives, and feature films to supplement coaching.

\section{Introduction of the Case Company}

In the 1950s, the Marriott franchise focused on two motels. The first was a Premier Inn airport motel outside Washington, D.C., accompanied by the Twin Bridges, an adjacent motel a few years later. Marriott became a brand name with the building of the second lodging. The Twin Bridges building was dismantled in 1990, but the Key Bridge 


\section{International Advanced Research Journal in Science, Engineering and Technology}

Vol. 8, Issue 7, July 2021

\section{DOI: 10.17148/IARJSET.2021.8710}

building is still in use as a full-service hotel. Marriott established Camelback Inn, its first resort hotel, in Arizona, USA, in 1967. With the launch of the Marriott in Acapulco, Mexico in 1969, Marriott Hotels \& Resorts made its first venture outside of the United States. Marriott Hotels \& Resorts had ventured to Europe by 1975, with the establishment of the Amsterdam Marriott hotel that year. Marriott officially opened Awesome America amusement parks in 1976 before selling them to Six Flags in 1984.

Marriott International owned and operated many of the properties in its portfolio throughout those first few aeons. In 1993, the corporation chose to spin off its property development owning business as Host Marriott, although keeping the Marriott International branding for hotel advisory services. Marriott Hotels \& Resorts debuted its first new room concepts in eleven years in September 2005. The guest apartments, dubbed spot, have elegance and modern technologies. Marriott stated in August 2020 that it's Create a Green Choice initiative would be phased off.

\section{Hotel services and facilities}

On nine levels, the hotel has 107 rooms, three of which are conference rooms. A wide range of services and amenities are available at the hotel. In-room coffee and tea, as well as a cash machine/ATM There is a daily housekeeping service, a Chauffeur service, and wheelchair-accessible accommodations. Newspapers are sent to rooms upon request, and they are also available in the lobby. Housekeeping is available 24 hours a day, concierge is available 24 hours a day, front desk is open 24 hours a day, safe deposit lockers are available 24 hours a day, and an entrance desk is available 24 hours a day. Clients might get straightforward advice and suggestions from a chauffeur driver, for example, as well as a friendly greeting..

\section{Hotel specialties}

When a guest arrives at the front desk, the restaurant offers attractive greeting sweets; the front desk employee allows the passenger to take the sweets and giving the client a good impression. DTS-Delighted to Service, the Fairfield by Marriott hotel's reservation office, is peculiar in that when personnel carry items to rooms, they avail a specific hamper. It informs the guest about the weather reports and headlines without saying anything about getting up. Clients can use a special gaming device to select the beverage they want to purchase at the bar. It's a small cube with six sides, each reflects a particular type of beverage; when he or she throws the crystal, he or she will choose his or her drink. The hotel provides a little golden pineapple medal to large dinner or conference delegates to wear on their shirts so everyone knows who they are and that they'll be well looked after.

The Training System

There are so many kinds of coaching accessible at the Fairfield by Marriott Hotel, with 15-minute trainings in each department that cover a variety of topics each day, like cleaning table procedures, beverage knowledge, and greeting customers. Once a week, English training is held, during which speaking, reading, and listening skills are taught and practised, with the majority of the topics being related to hotel employment. At the same time, role play is a part of English training. For leaders, supervisors, and managers, there are several departmental and organisational trainings.

The Marriott Hotel Group has its own training programme, called passport to success, which includes eight levels, beginning with Level 1-learning the fundamentals of hospitality and services, as well as knowing Marriott history, culture, and service spirit. Employees' understanding of hotel services and safety issues will be examined beginning at Level 2. The tests will become more thorough as the amount of work increases, and other departments' knowledge will be addressed. Level 2 tests, for example, hotel general knowledge and safety concerns; it is a review of the previous level training and aids in understanding the findings of level 1 training. The essentials and criteria for food and beverage services in rooms are covered at Level 5. The higher level you must complete the longer you remain in the hotel. In addition, all Marriott hotels accept the passport of finished trainings. The training programme assists specialists in improving their operational excellence and quality, as well as providing technical information and preparing them for life's changes.

Research Methodology

This chapter will introduce methodological approaches, examine the research methodologies used in this study, how data is acquired, and discuss the research's findings. A validity and reliability analysis will be performed in the last section.

\section{Research Methods}

In the quantitative component of this research endeavour, there are two types of research methods: qualitative research and quantitative research; both are used. Quantitative study was conducted by delivering surveys to staff in the Food \& Beverage department, while qualitative research was conducted by conducting individual interviews with the Assistant Human Resource Manager, and Training Manager. 
Quantitative Research

"Quantitative research enables the researcher to become acquainted with the subject or subject under investigation and, in some cases, to produce hypotheses to be verified." Quantitative research seeks to verify the data gathered in order to analyses it and determines the last part of goal. It aims on big figure of responders. In this study, a quantitative method was employed to gather data from F\&B department employees about their perceptions regarding hotel staff training. It is simple to have a concise and research - based view on the opinions with the help of quantitative research method by survey questions and analysing with SPSS, and interviewing few of the staff furthermore, it is not possible to interview every employee individually.

\section{Qualitative Research}

"Qualitative research, primarily as an interpretive approach but also as a descriptive design, plays a significant role in assisting marketing decision-making." Malhotra and Birks this means that qualitative research will be used to discover "why" rather than "how." Qualitative research is not focused on data and aims to develop an early knowledge of the research.. Qualitative can be used alone or to support quantitative research. For this research work, in order to get a better understanding of the training system, the trainingse general information and their effects etc. the author used the depth interview (Figure 3) to support the quantitative research.

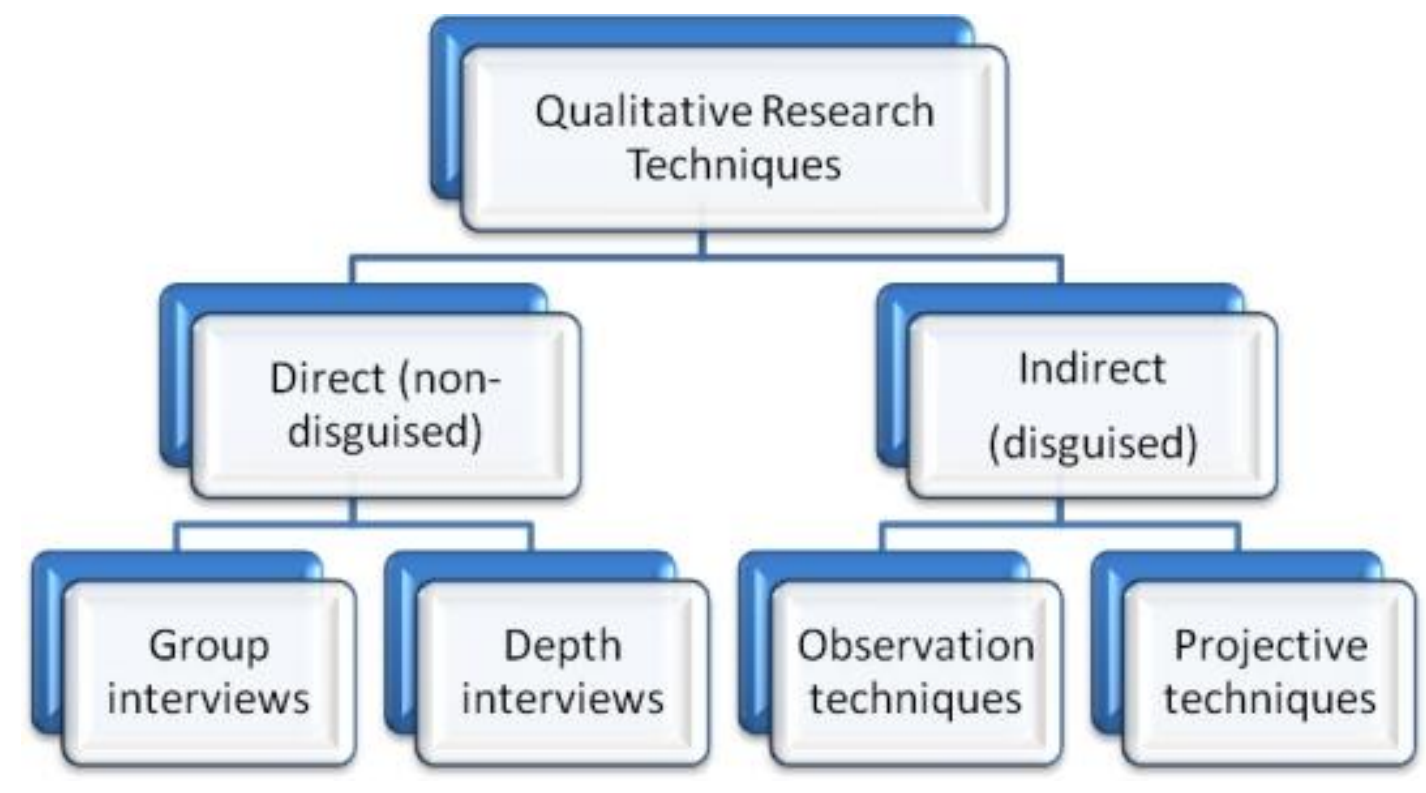

Figure 3 Qualitative Research Techniques (Malhotra \& Birks 2003, 158) Data Collection The data of this study is the primary data coming from the survey and the interviews.

The study's sample size is all employees in the Food \& Beverage department, and the questionnaire is regarding the hotel's staff training system. The questions on the questionnaire are divided into two sections: the first section is collecting general details, such as gender, age, prior hospitality education, prior hotel working experience, and so on; the second section is about the training they received in the hotel and what opinions they have about the training system; and the third section is about how they realise the priority of the development program. Because the questionnaires were distributed out and forwarded to the author by e-mail, it took longer than expected to gather full data. There were 76 questions addressed to the Food and Beverage department, with 53 responses, comprising Chinese restaurant, western restaurant, kitchens, banquet, bar, and bakery. The response rate is at $69.7 \%$.

The interview questions were created prior to the interviews and are divided into three sections: the first section is about the interviewees' background information, positions, work experience, and work tasks, for example; the second section is about the case hotel's training programmes' motives and targets; and the third section is about the training programmes' improvements. Individual interviews with the Assistant Manager from the Human Resource department, the Training Manager, and the original supervisor of the western restaurant were conducted over the phone. They are staff training experts, and their viewpoints represent a variety of perspectives from various perspectives. Interviews with the Assistant Human Resource Manager and Training Manager took place on May 29, 2021, and the supervisor also on 29, May 2021. 


\section{RESULTS AND ANALYSIS OF THE SURVEY}

Employees' background Information

The quantitative research results and analysis are displayed below; from the statistics, we can observe the fundamental details of the customers and their sentiments toward the training activities held at the Fairfield Marriott Hotel.

\section{Gender}

The respondents have returned 53 of the 76 questionnaires that were sent out; there are 32 male respondents and 21 female respondents, respectively. The ratio of males is roughly 3:2. The discrepancy in gender is due to the fact that in the Food and Beverage sector, both the Chinese and Western kitchens have mostly male employees.

\section{Age}

The second question is to learn about both the ages of employees so that a link may be established between age groups and trainings.

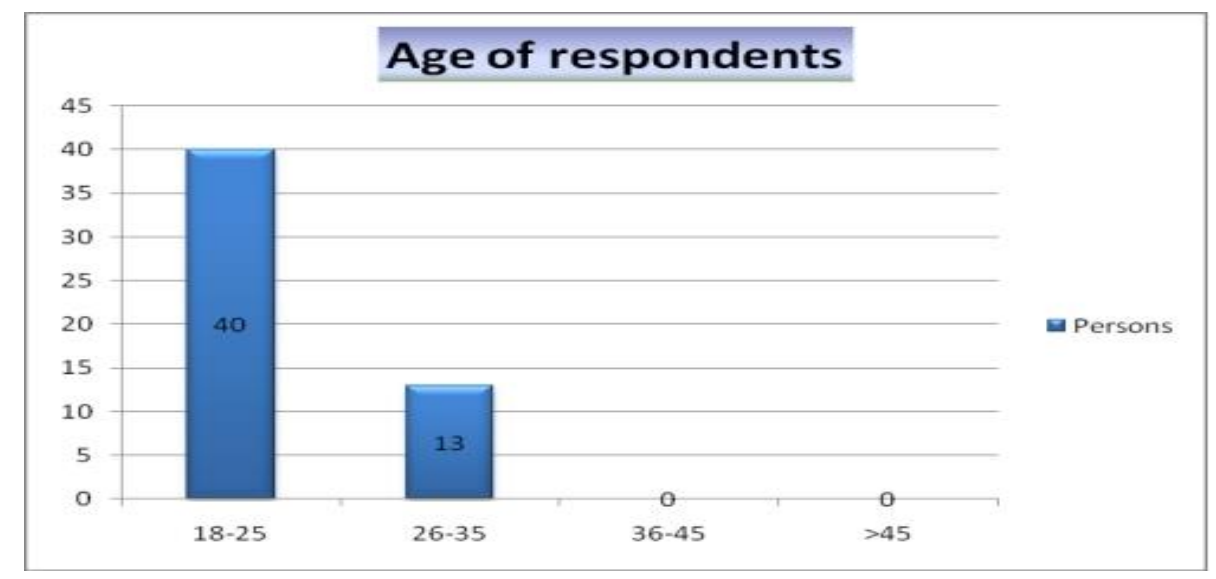

Figure 4 Age of the respondents

Figure 4 shows that the main age group in Food and Beverage department is between 18 and 25; the rest 13 respondents are in the age of 26 to 35 .

Because the tavern and cafe industry operateson a changing and highly competitive environment,"young individuals between the ages of 18 and 35 are most commonly picked to work in this industry because they can quickly and rea dily adjust to new situations."

When providing training, the HR department should consider the age groupings; young workers dislike theoretical $b$ ut accept more engaging material; employees between the ages of 26 and 35, on the other hand, can take both. The e fficacy of trainings may be increased if this factor was taken into account.

\section{Work experience}

This inquiry is investigated to identify information about employees' previous similar job experience in the industry, with the goal of determining the need for training.

\section{Training}

The trainings were about hotel general introduction, customer service, computer system usage, departmental guide, and other topics. 43 respondents did not receive training when they started, while 10 others did. Because it is not possible to provide training for each new employee because they are hired at different times, according to the Assistant Manager of Human Resource Department (Assistant HR Manager 2009), is appropriate and cost effective to conduct coaching to the group of fresh arrival.

Appropriate guidance prior to the task, on the other hand, assist employees in swiftly becoming accustomed to the environment and work responsibilities, as well as avoiding barriers and potential mishaps while on the job. Appropriate training prior to work leads to improved attitudes toward their jobs.

The human resource department should also emphasize employee training, whether it takes place before or after the start of work, and the benefits that come with it, so that they pay increasing emphasis to all of the upcoming trainings. The HR department should be regarded as an essential part of trainings and should make every effort to eng age in their 


\section{International Advanced Research Journal in Science, Engineering and Technology}

Vol. 8, Issue 7, July 2021

\section{DOI: $10.17148 /$ IARJSET.2021.8710}

planning in order to assist employees in improving, assuring business growth, and having more success from staff trainings.

\section{Frequency of training}

Employees say that training takes too long every day, that the contents of trainings repeat themselves, and so on. Trainers and HR DEPARTMENT, on the other hand, have opposing views on repeating training (Training Manager 2009); they believe that repeated training improves employees' mastery of knowledge and abilities, allowing them to give better customer service. The management team has high expectations for training; however, the results have not met those expectations thus far. As a result, management and employees should communicate more effectively so that employees are ready to participate in training and learn more from it.

\section{Facts about training}

The next three questions will determine if the trainings are necessary or optional, whether employees must apply for them, and where they will be held. It is essential, and every Marriott Hotel employee is expected to grow through various types of training. In order to build better training plans, the management team may better assess the personnel by acquiring a deeper understanding of their personalities, what they excel at, and what they lack.

The majority of trainings make use of hotel facilities, such as training rooms, restaurants, kitchens, and bars.

The importance of training

This is a question asking participants to indicate the relevance of various factors in order of priority, from most crucial to least essential. The replies may only depict the employees' own thoughts, but they also reveal their feelings at current classes.

\begin{tabular}{|c|c|c|c|c|c|c|c|c|c|}
\hline & $\begin{array}{l}\text { Most } \\
\text { Impor } \\
\text { tant }\end{array}$ & $\begin{array}{l}2 n \\
d\end{array}$ & 3rd & 4th & 5 th & 6th & 7th & 8th & 9th \\
\hline $\begin{array}{l}\text { Motivates } \\
\text { employeeand } \\
\text { helps them } \\
\text { perform better }\end{array}$ & 23 & 15 & 4 & 5 & 4 & 0 & 1 & 1 & 0 \\
\hline $\begin{array}{l}\text { Encourageself } \\
\text { Development } \\
\& \text { Self } \\
\text { confidence }\end{array}$ & 2 & 7 & 5 & 2 & 4 & 8 & 8 & 16 & 1 \\
\hline $\begin{array}{l}\text { Management } \\
\text { team can } \\
\text { evaluate } \\
\text { employees } \\
\text { performance }\end{array}$ & 14 & 15 & 9 & 7 & 3 & 2 & 2 & 1 & 0 \\
\hline $\begin{array}{l}\text { Sustains a } \\
\text { positive } \\
\text { attitude toward } \\
\mathrm{s} \quad \text { customer } \\
\text { service }\end{array}$ & 3 & 2 & 9 & 12 & 4 & 7 & 8 & 7 & 0 \\
\hline $\begin{array}{l}\text { Improves } \\
\text { communication } \\
\text { between } \\
\text { Management a } \\
\text { nd employee }\end{array}$ & 5 & 10 & 8 & 12 & 10 & 6 & 2 & 0 & 0 \\
\hline $\begin{array}{l}\text { Reduces } \\
\text { accidents } \\
\text { and safety } \\
\text { violations }\end{array}$ & 2 & 3 & 4 & 11 & 12 & 9 & 10 & 2 & 0 \\
\hline $\begin{array}{l}\text { Helps } \\
\text { organizational } \\
\text { development }\end{array}$ & 2 & 1 & 11 & 1 & 5 & 7 & 15 & 11 & 0 \\
\hline
\end{tabular}




\section{International Advanced Research Journal in Science, Engineering and Technology}

Vol. 8, Issue 7, July 2021

DOI: 10.17148/IARJSET.2021.8710

\begin{tabular}{|l|l|l|l|l|l|l|l|l|l|}
\hline $\begin{array}{l}\text { Introducingnew } \\
\text { technologies in } \\
\text { Time }\end{array}$ & 0 & 0 & 3 & 3 & 11 & 14 & 7 & 15 & 0 \\
\hline Not important & 1 & 0 & 0 & 0 & 0 & 0 & 0 & 0 & 52 \\
\hline
\end{tabular}

As shown in above tables, 23 respondents chose "Motivates employees and helps them to perform better" as the most important factor of staff training. Then for the second importance 15 respondents chose "Management team can evaluate employeese performance" and "Motivates employees and helps them to perform better". 11 respondents thought trainings "Helps organizational development" is the third most important reason of trainings. Except one respondent considered training not important, 16 participants chose "Encourages self development \& self-confidence" as the least important reason.

\section{Suggestions:}

1. Assist employees in learning about and appreciating the value of staff training. The human resource department could explain to the employees the training's objectives and how they would profit from the training; in the meantime, the employees should be instructed how they might apply what they have learned in the trainings in the future. Employees and trainees from sister hotels will be invited to share their insights, which is an excellent opportunity to educate employees about the importance of staff training.

2. Improve management-employee communication by soliciting input from employees to learn what they appreciate and what may be modified in trainings to achieve better results. And trainers can see that while giving trainings, some colleagues do not voice their dissatisfaction with the trainings by not expressing it. Furthermore, personnel from the human resource department could attend the trainings to resolve individuals and get a sense of what it's like to be a trainee. Trainings will be more effective if everyone understands each other properly.

3. Assist employees in realising that the primary goal of training is to improve themselves. Employees did not regard self-development as the most primary criterion for trainings, thus they should be led in the appropriate path, which is to improve themselves and customer service, not for competitiveness or elevation or other reasons.

Finally, the relevance of staff training is discovered in this study, and some ideas are made to assist the case hotel's human resource department in solving present challenges in staff training as stated above. It will take time to fix the current condition, and it will require the collaboration of both the management group and the personnel. I sincerely hope that this research will be useful in assisting the hotel's Human Resource Development.

\section{REFERENCES}

1. Alan Price. 2007. Human Resource Management in a business context. 3rd Edition. London. Thomson Learning.

2. David, A. Decenzo and Stephen, P. Robbins 2007. Fundamentals of Human Resource Management. 9th Edition. USA. Wiley.

Dennis, Nickson 2007. Human Resource Management For The Hospitality and Tourism Industries. Elsevier.

Farhad, Analoui 2007. Strategic Human Resource Management. London. Thomson.

Gary, Dessler 2006. A Framework for Human Resource Management. 4th edition. New Jersey. Pearson Prentice Hall.

Gary, Dessler. 2007. Human Resource Management. 10th Edition. Prentice Hall Inc.

Ian Beardwell, Len Holden \& Tim Claydon. 2004. Human Resource Management A Contemporary Approach. 4th edition. England.

Pearson Education Limited.

8. John R. Walker. 2007. Introduction to Hospitality Management. 2nd Edition. New Jersey. Pearson Education, Inc.

9. John Stredwick. 2002. Managing People in a Small Business. UK. Kogan Page.

10. Kerry, L. Sommerville 2007. HospitalityEmployee Management And Supervision, concepts and practical applications. New Jersey. John Wiley \& Sons.

11. Mary, L. Tanke 2001. Human Resource Management for the hospitality industry.

12. Michael Armstrong 1992. Human Resource Management Strategy \& Action. London. Kogan Page.

13. Naresh K. Malhotra \& David F. Birks. 2003. Marketing Research An Applied Approach. 2nd European edition. England. Pearson Education Limited.

14. Robert H. Woods. 2006. Managing hospitality Human Resources. 4th Edition. USA. Educational Institute. American Hotel \& Lodging Association.

15. Susan, D. Mcclelland 2002. The Graduate School University of Wesconsin Stout. A Training Needs Assessment for the United Way of Dunn County Wisconsin.

16. Nahid Golafshani. 2003. University of Toronto. Understanding Reliability and Validity in Qualitative Research.

\section{Interview}

1. Restaurant supervisor, 29 May, 2021. Fairfield by Marriott Hotel, Chennai OMR. Telephone interview.

2. Assistant Human Resource Manager, 29 May, 2021.Fairfield by Marriott Hotel, Chennai OMR. . Telephone interview.

3. Training Manager, 29 May, 2021. Fairfield by Marriott Hotel, Chennai OMR.. Telephone interview. 
International Advanced Research Journal in Science, Engineering and Technology

Vol. 8, Issue 7, July 2021

DOI: $10.17148 /$ IARJSET.2021.8710

\section{BIOGRAPHY}

I am Punitharaj Devaraj from first year PhD student in Management studies at Bharat Institute of Higher Education and Research - Bharath University examining serious play of Time management cultures in Hospitality Industry. I am working in hotel for past seventeen years. Currently, am working and interested to do research on an exploration of Time-Management behaviours of Executive Chef. 